\title{
E-LEARNING USER INTERFACE ACCEPTANCE BASED ON ANALYSIS OF USER'S STYLE, USABILITY AND USER BENEFITS
}

\author{
Ramadiani $^{1}$, Rodziah binti Atan ${ }^{2}$, Mohd. Hasan Selamat ${ }^{2}$, Noraini Che $\mathbf{P a}^{2}$, and Rusli Abdullah ${ }^{2}$ \\ ${ }^{1}$ Computer Science, Natural Resourches and Mathematic Faculty, Mulawarman University \\ ${ }^{2}$ Information System, Computer Science and Information Technology Faculty,
} Putra Malaysia University

Email: mmi_ugm04@yahoo.com

\begin{abstract}
E-learning does not function properly if the system is not in accordance with user needs. This study aims to establish an evaluation model for e-learning user interface according to user acceptance. The model is designed based on three categories: user learning style, usability and user benefits. Results of measurements of the three categories will determine the level of user acceptance of the e-learning interface. The data were taken using a questionnaire which was distributed to $125 \mathrm{ELS}$ students from various countries. Then processed using SEM and Lisrel v8.80. This paper presents experimental set up for the general research and some results for technology acceptance theories.
\end{abstract}

Keywords: e-Learning, User Interface, User's Style, Usability, User Benefit.

\begin{abstract}
Abstrak
E-learning tidak akan berfungsi dengan baik jika sistem ini tidak sesuai dengan kebutuhan pengguna. Penelitian ini bertujuan untuk membangun sebuah model evaluasi untuk antarmuka pengguna e-learning sesuai dengan penerimaan pengguna. Model ini dirancang berdasarkan tiga kategori: gaya belajar pengguna, kegunaan, dan manfaat pengguna. Hasil pengukuran dari tiga kategori akan menentukan tingkat penerimaan pengguna antarmuka $e$ learning. Data diambil dengan menggunakan kuesioner yang dibagikan kepada 125 siswa ELS dari berbagai negara. Kemudian diolah dengan menggunakan SEM dan Lisrel v8.80. Paper ini menyajikan set up eksperimental untuk penelitian umum dan beberapa hasil untuk teori penerimaan teknologi.
\end{abstract}

Kata kunci: e-Learning, User Interface, Style Pengguna, Usability, Manfaat Pengguna.

\section{Introduction}

E-learning is a method of learning that is offered by many universities and educational institutions to support their learning process. Basically, the concept of e-learning is the provision of equal educational facilities to learn in a conventional school. The role of e-learning is expected to help the role of educational institutions an conventional training. E-learning process has different characteristic compared to common education. According to [1] E-learning has personalized for student, focused on student and is directly controlled by themselves, occurs only when required and has the strictly necessary duration, communicated by technology on the basis student has gotten knowledge and need proactive roles.

The e-learning is a distance learning system which offers training courses and custom tailors to the needs of learners. An integrated environment which combines the advantages of e-learning and traditional classroom is called as blended eeducation [2]. But, unused user interfaces are probably the single largest reasons why on all sides of interactive system computers and elearning fall in actual use. The design of applications purposes in term of ease of use is not an easy task [3]. E-learning will become less optimal if the system is not effective used in accordance with user needs [1]. 


\section{Related Theories}

\subsection{User Interface Evaluation}

The system interface is used to communicate with a user in an interactive system. The system interface can be divided into two sections; a front interface and back-end interface [1]. E-learning interface design is especially critical, as the learning effectiveness and interface design are substantially intertwined. To design an e-learning interface should be determined by how people learn and the tasks they need to perform in the program. There are some features in the user interface that are still less efficient [3]. Many theories that discuss the interface evaluation design, but the fact still weak and does not work in accordance with the e-learning user interface expected [4]. Table I shows the related works in elearning user interface acceptance.

TABLE I

E-LEARNING USER INTERFACE EVALUATION

\begin{tabular}{|c|c|}
\hline Model & Research Variables \\
\hline $\begin{array}{l}\text { Criteria for interface } \\
\text { design and evaluation, } \\
\text { Scapin (1990) }\end{array}$ & $\begin{array}{l}\text { user explicit control, adaptability, } \\
\text { error management, compatibility, } \\
\text { guidance, consistency, user } \\
\text { workload, significance of codes }\end{array}$ \\
\hline $\begin{array}{l}\text { Quantitative } \\
\text { Evaluation, Olga, } \\
\text { (2004) }\end{array}$ & $\begin{array}{l}\text { Speed of user's work, Complexity } \\
\text { user's work, user's mistakes, } \\
\text { Speed of studying, Subjective } \\
\text { satisfaction }\end{array}$ \\
\hline $\begin{array}{l}\text { AHP Model. Yong } \\
\text { et.al (2007) }\end{array}$ & $\begin{array}{llr}\text { Interaction } & \text { Support, } & \text { Function } \\
\text { Support, } & \text { User } & \text { Support, } \\
\text { Information } & \text { Support, } & \text { Device } \\
\text { Capacity } & & \end{array}$ \\
\hline $\begin{array}{l}\text { HELAM ( Hexagonal } \\
\text { e-learning Assessment } \\
\text { Model), Ozkan (2009) }\end{array}$ & $\begin{array}{l}\text { system quality, service quality, } \\
\text { content quality, learner } \\
\text { perspective, instructor attitudes, } \\
\text { supportive issues. }\end{array}$ \\
\hline $\begin{array}{l}\text { Inherent Structure in } \\
\text { e-learning, Sfenrianto } \\
\text { et.al. (2011) }\end{array}$ & $\begin{array}{l}\text { Learning style, Motivation, } \\
\text { Knowledge-ability }\end{array}$ \\
\hline
\end{tabular}

"The often problem is that it is impossible to determine which user interface design variant is better" [5]. Empirical evaluation of subjective selection criteria cannot be the best interface. Therefore quantitative evaluation methods are needed user interface. Different interface designs can be evaluated with quantitative methods priority criteria. While [3] argues that interface design e-learning should be a goal, an integrated component of the overall e-learning products.

User interface becomes the major channel to convey information in e-learning context: a welldesigned and friendly interface is thus the key element in helping users to get the best results quickly [6]. Interface settings will affect the quality of students learning that accommodates their needs in terms of personalizing the content, structure, and presentation.

\subsection{User's Learning Style}

User's Learning or Style User's Style is student factors in learning such as, learning style, motivation, and knowledge ability. User learning style should be considered in the adaptive elearning development in order to optimize learning process [7].

Learning Style refers to how a learner perceives, interacts with, and responds to the learning environment; it is a measure of individual differences [8]. According to [9] User Learning Style is developed from the individual's physiological characteristic, will be influenced by: 1) Psychology development, social environment and education experience. 2) Learning time, study habits, learning approach, gender, ethnicity, learning time, the learning resource and the process of learn. 3) Record the learning information for each student: the individual learning style, preferred study habits, learning approach, his dynamic learning situation and even detail information.

Learning motivation is an individual's characteristic and consistent approach to organizing and processing information. The students learning motivation is divided into five categories: effort, confidence, satisfaction, sensory interest and cognitive interest [7]. From these categories, effort is a fundamental indicator of a student's motivation. The exertion of effort in learning can be as a positive parameter. The student's effort is the amount of time the learner spends on learning and participation.

The student's ability is also another factor that should be considered. The student's ability can be seen from the level of knowledge in their learning performance. To measure the learning performance is recognising the knowledge objectively through evaluation, such as quiz, class exercise, and exam [7].

\subsection{Usability Evaluation}

Usability is a quality attribute that assesses how easy user interfaces are to use. The word "usability" refers to a method for improving easy of use during the design process [10] [11] [12]. Definition of usability based on 3 different standardization organizations: A set of attributes that bear on the effort needed for use and on the individual assessment of such use, by a stated or implied set of users (ISO/IEC 9126, 1991). The extent to which a product can be used by specified users to Achieve specified goals with effectiveness, efficiency and satisfaction in a specified context of use (ISO 9241 to 11.1998). The ease with which a user can learn to operate, 
prepare inputs for, and interpret outputs of a system or component (IEEE Std.610.12-1990) [13].

Usability is important to determine whether something is useful. It matters that something is easy but it is not what you want [5][14][15]. Although there are many individual methods for evaluating usability; they are not well integrated into a single conceptual framework that facilitate their usage by developers. There are several standards or conceptual models for usability, and not all of this standards or models describe the same operational definitions and measures [16]. It needs a measurement model and a structural model for evaluating the e-learning user interface acceptance model [8] [17].

\subsection{The Technology Acceptance Model (TAM)}

There are several models that are built to analyze and understand the variables that affect the user acceptance of information technology [18], among others; Theory of Reasoned Action (TRA), Theory of Planned Behaviour (TPB), and the Technology Acceptance Model (TAM). TAM models are developed from a psychological theory, which describes the behavior of computer users that are based on beliefs, attitudes, desires and relationships user behavior. These models aim to explain the main factors of user behavior on user acceptance of technology as refered in Figure.1. This model places the attitudinal factors of individual user behavior with variables: ease of use (ease of use), utility (usefulness), use (Attitude Toward Using), behavior to keep using (Behavioral Intention To Use), the real conditions of use of the system (Actual System Usage).

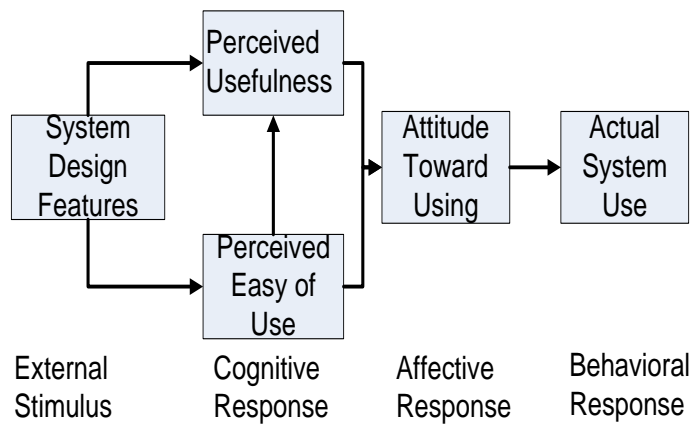

Fig 1. TAM Evaluation Theory

\section{Research Design}

\subsection{Research Hypothesis Model}

User Interface Acceptance in this interface evaluation focuses on 12 indicator variables [Figure. 2]: $\xi=$ User Interface Acceptance; $\eta_{1}=$ User's Style; $\eta_{2}=$ Usability; $\eta_{3}=$ User Benefit $y_{1}=$ Knowledge ability; $y_{2}=$ Motivation; $y_{3}=$ Learning Style; $y_{4}=$ Knowability; $\quad y_{5}=$ Operability; $y_{6}=$ Efficiency; $\quad y_{7}=$ Robustness $; \quad y_{8}=$ Safety; $y_{9}=$ Subjective $\quad$ Satisfaction; $\quad y_{10}=$ Media elements; $\quad y_{11}=$ Communicativeness $; \quad y_{12}=$ User Expectation. The complete description about this research hypotheses as shown in Figure 3.

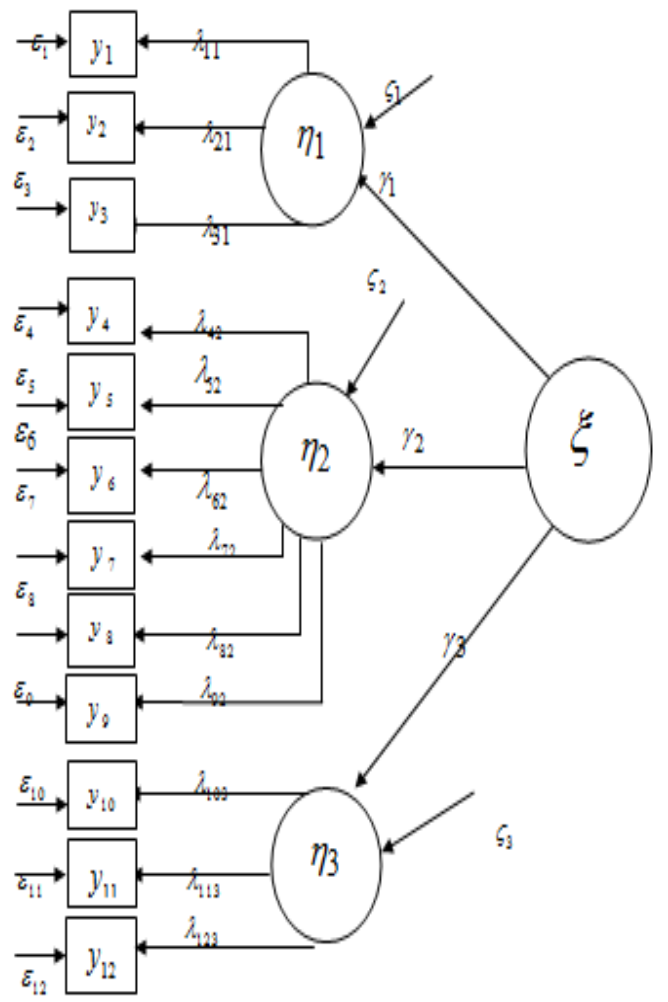

Fig 2. Research Hypotheses

The model of User Interface Acceptance in this study is a model 2ndCFA. For each of the research hypotheses will be defined in a statistical hypothesis testing is necessary as a means of hypothesis. Testing multiple statistical hypotheses through estimation of the parameters $\gamma$ and $\lambda$ contained in the research and LISREL models. In statistical hypothesis $H_{0}$ if the corresponding parameter is zero, while $H_{a}$ if the parameter is not zero. Thus if $H_{0}$ is rejected, it means that the research hypotheses concerned accepted. As for some of the hypotheses for this research are as referred in Figure 3. 


\begin{tabular}{|c|c|c|c|}
\hline$H_{116}: \lambda_{11}=0$ & $H_{11 \mathrm{~s}}: \lambda_{11} \neq 0$ & $H_{216}: \lambda_{21}=0$ & $H_{21_{s}}: \lambda_{21} \neq 0$ \\
\hline$H_{36}: \lambda_{31}=0$ & $H_{31}: \lambda_{31} \neq 0$ & $H_{420}: \lambda_{42}=0$ & $H_{42_{s}}: \lambda_{42} \neq 0$ \\
\hline$H_{520}: \lambda_{52}=0$ & $H_{52}: \lambda_{52} \neq 0$ & $H_{62}: \lambda_{62}=0$ & $H_{62}: \lambda_{62} \neq 0$ \\
\hline$H_{720}: \lambda_{72}=0$ & $H_{72_{a}}: \lambda_{72} \neq 0$ & $H_{820}: \lambda_{82}=0$ & $H_{82}: \lambda_{82} \neq 0$ \\
\hline$H_{920}: \lambda_{92}=0$ & $H_{92}: \lambda_{92} \neq 0$ & $H_{103}: \lambda_{103}=0$ & $H_{103_{s}}: \lambda_{103} \neq 0$ \\
\hline$H_{113}: \lambda_{113}=0$ & $H_{113}: \lambda_{113} \neq 0$ & $H_{123}: \lambda_{123}=0$ & $H_{123_{s}}: \lambda_{123} \neq 0$ \\
\hline$H_{134}: \gamma_{134}=0$ & $H_{134_{s}}: \gamma_{1} \neq 0$ & $H_{144_{0}}: \gamma_{2}=0$ & $H_{144}: \gamma_{2} \neq 0$ \\
\hline$H_{154_{0}}: \gamma_{3}=0$ & $H_{155_{s}}:$ & & \\
\hline
\end{tabular}

Fig 3. Research Hypotheses

We can see the User Interface Acceptance Model attributes as shown in tables II.

TABLE II

USER INTERFACE ACCEPTANCE ATTRIBUTES

\begin{tabular}{|c|c|c|}
\hline Var. & GOALS & ATTRIBUTES \\
\hline & $\begin{array}{l}\text { User Profile } \\
\text { (descriptive analysis) }\end{array}$ & Ethnicity \\
\hline Y1 & Knowledge ability & Grades \\
\hline Y2 & Motivation & CIEP Level \\
\hline Y3 & Learning style & $\begin{array}{l}\text { learning time } \\
\text { study habits }\end{array}$ \\
\hline Y4 & Knowability & $\begin{array}{l}\text { Learnability, } \\
\text { Understandability } \\
\text { Memorability }\end{array}$ \\
\hline Y5 & Operability & $\begin{array}{l}\text { Ease of use } \\
\text { Effectiveness } \\
\text { Flexibility }\end{array}$ \\
\hline Y6 & Efficiency & $\begin{array}{l}\text { User workload } \\
\text { Efficiency } \\
\text { Productivity }\end{array}$ \\
\hline Y7 & Robustness & $\begin{array}{l}\text { Error Management } \\
\text { Trustfulness } \\
\text { Errors }\end{array}$ \\
\hline Y8 & Safety & $\begin{array}{l}\text { Safety } \\
\text { Secure } \\
\text { Comfortable }\end{array}$ \\
\hline Y9 & $\begin{array}{l}\text { Subjective } \\
\text { Satisfaction }\end{array}$ & $\begin{array}{l}\text { Attractiveness } \\
\text { Compliance } \\
\text { Satisfaction }\end{array}$ \\
\hline Y10 & Media element & $\begin{array}{l}\text { Usefulness } \\
\text { Completeness } \\
\text { Increase }\end{array}$ \\
\hline Y11 & Communicativeness & $\begin{array}{l}\text { Simple } \\
\text { Intuitive } \\
\text { Perceptive }\end{array}$ \\
\hline Y12 & User Expectation & $\begin{array}{l}\text { User need } \\
\text { Capability } \\
\text { Expectation }\end{array}$ \\
\hline
\end{tabular}

\section{Results and Analysis}

The questionnaires was distributed to 125 ELS language Center students in Malaysia who come from 13 countries (Figure 4). The minimum sample size recommended [19] for the sample in this study, depending on the number of variables to be studied. The formula is as follows: $\mathrm{k}(\mathrm{k}+1)$ / 2 , where $\mathrm{k}$ is the number of variables. it needs at least samples to calculate the minimum model of in this research is $12(12+1) / 2=78$ samples.

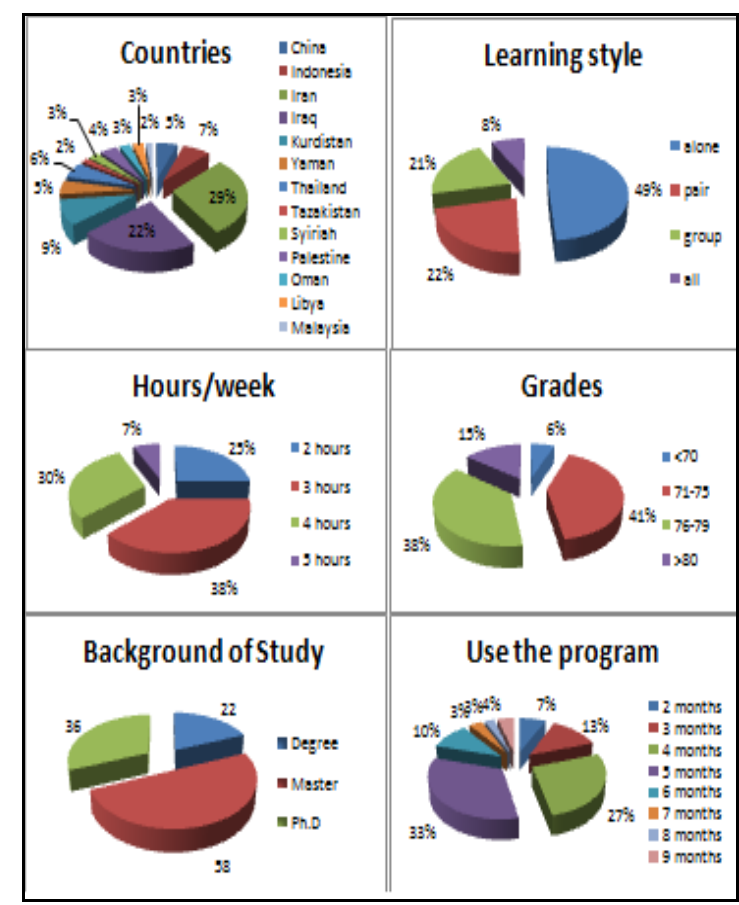

Fig 4. Research Respondents

The data collected in this study is ordinal data and the estimation method used is the method of ML (maximum likelihood). The data was processed by using SEM and Lisrel v8.80. The result of model measurement is very significant correlation between variables. Variable User's style, consisting of $\mathrm{Y} 1, \mathrm{Y} 2, \mathrm{Y} 3$, which also correlated with variables Y11, Y12. Usability of e-learning system, consisting of Y4, Y5, Y6, Y7, Y8, Y9, Y10 plus correlation with variable Y2, and the last indicator User's benefit, consisting of Y10, Y11, Y12, plus variable Y5, Y6, Y9 as shown in Figure 5 \& Figure 6. Model I mesurement results in Figure 5: User's Style $=\mathrm{t}$ value $=8.09, \gamma=0.73, \mathrm{R}^{2}=0.53$. Usability $=\mathrm{t}$ value $=7.42, \gamma=0.96, R^{2}=0.92$. User Benefits $=\mathrm{t}$ value $=7.04, \gamma=0.80, \mathrm{R}^{2}=0.63$. Model II mesurement results in Figure 6: User's Style $=\mathrm{t}$ value $=8.43, \gamma=0.77, \mathrm{R}^{2}=0.59$. Usability $=\mathrm{t}$ value $=7.83, \gamma=0.95, \mathrm{R}^{2}=0.90$. User Benefits $=\mathrm{t}$ value $=7.51, \gamma=0.84, \mathrm{R}^{2}=0.71$. 


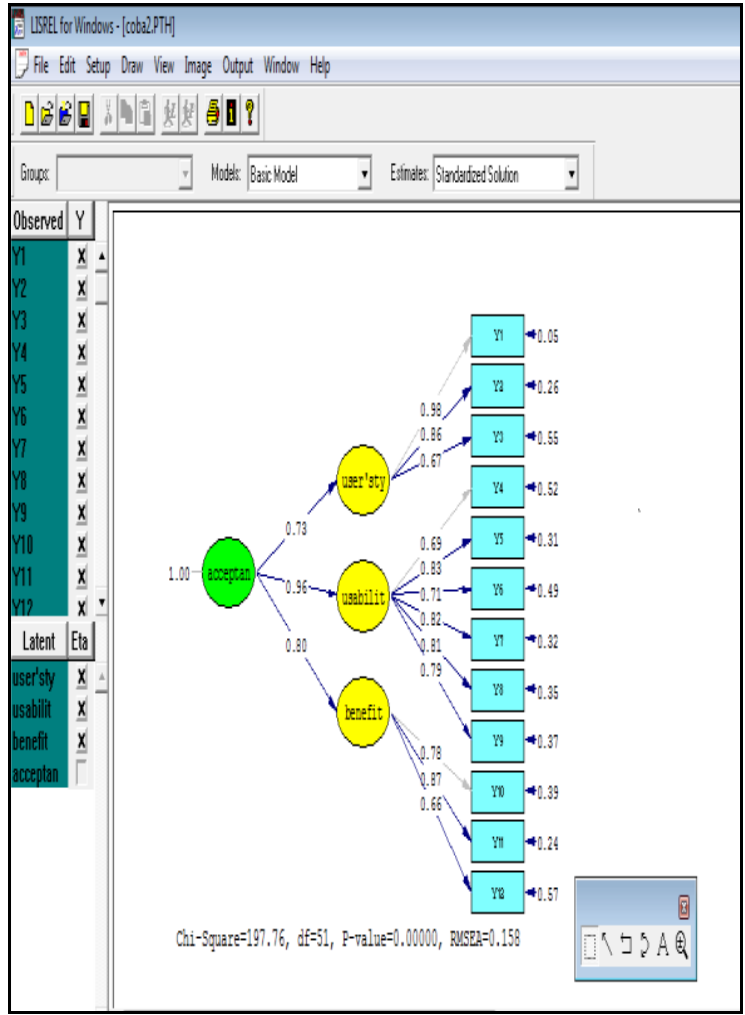

Fig. 5 Model I Initial Measurement

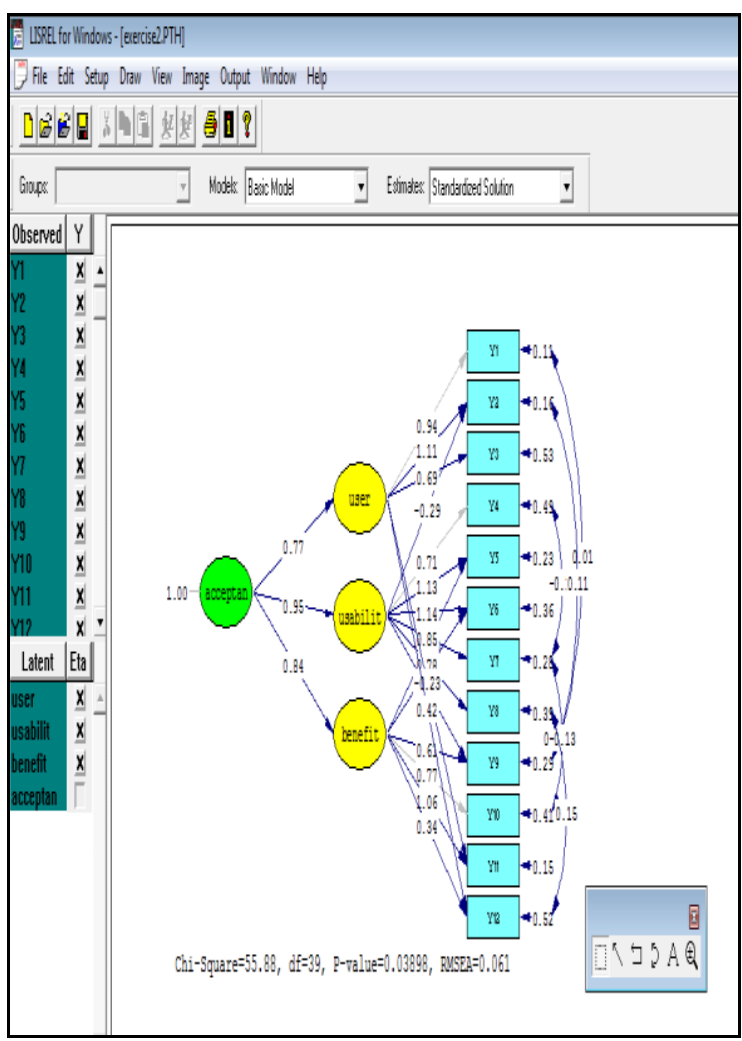

Fig 6. Model II Suggestion Measurement
TABLE III RESEARCH HYPOTHESIS RESULTS

\begin{tabular}{lcccc}
\hline Name & $\begin{array}{c}\text { Lambda } \\
\text { Gamma }\end{array}$ & t value & $H_{0}$ & $\begin{array}{c}\text { Research } \\
\text { Hypothesis }\end{array}$ \\
\hline $\begin{array}{l}\text { Knowledge } \\
\text { ability }\end{array}$ & 2.90 & $*$ & & \\
Motivation & 1.18 & 5.41 & rejected & H21 accepted \\
Learning style & 0.66 & 7.20 & rejected & H31 accepted \\
Know-ability & 1.21 & 6.98 & rejected & H42 accepted \\
Operability & 0.84 & 6.12 & rejected & H52 accepted \\
Efficiency & 0.66 & 6.89 & rejected & H62 accepted \\
Robustness & 1.36 & 6.18 & rejected & H72 accepted \\
Safety & 0.84 & 6.32 & rejected & H82 accepted \\
Subjective & 1.74 & 6.47 & rejected & H92 accepted \\
Satisfaction & & & & \\
Media element & 0.93 & 5.58 & rejected & H103 accepted \\
Communicative & 0.97 & 3.80 & rejected & H113 accepted \\
User expectation & 5.54 & 6.66 & rejected & H123 accepted \\
User style & 0.73 & 8.09 & rejected & H134 accepted \\
Usability & 0.96 & 7.42 & rejected & H144 accepted \\
User Benefit & 0.80 & 7.04 & rejected & H154 accepted \\
\hline
\end{tabular}

TABLE IV

VARIANCE EXTRACTED AND

CONSTRUCT RELIABILITY OF MODEL

\begin{tabular}{lcc}
\hline Variables & $\begin{array}{c}\text { Construct Reliability } \\
(>0.70)\end{array}$ & $\begin{array}{c}\text { Variance Extracted } \\
(>0.50)\end{array}$ \\
\hline User style & 0.88 & 0.71 \\
Usability & 0.90 & 0.61 \\
User Benefit & 0.82 & 0.60 \\
Acceptance & 0.73 & 0.69 \\
\hline
\end{tabular}

Based on the statistical data, the model of elearning user interface, has a highly significant correlation values and strong construction between variables, which is evidenced by the size of the construct reliability values above 0.70 and the value of its variance extracted 0.50 . $\mathrm{T}$ value exceeds the critical value also has a significant level of 1.96 to 0.05 which means that the relevant variables significantly related to the concept of design-related. The high load factor (0.70) of each variable also proves the strength of the relationship between variables with its constructs (table III and table IV).

Research generates model was estimated before we tested the Goodness of fits of the user interface acceptance model by using LISREL v8.80. The result of GOF measurement in this study also described information about the guidelines and limits the admissibility of GOF levels as shown in Table V.

Table V shows the goodness of fit statistical theories implied in this study, column 1 represents the goodness of fit theories, column 2 indicator the target, column 3 is model I measurement and column 4 is model II measurement. Chi-square value shows the deviation between the sample covariance matrix and the model (fitted) 
covariance matrix. Chi-square is a measure of the poor fit of a model. Chi-square value of 0 indicates that the model has a perfect fit. Goodness of fit indices (GFI) is a measure of the accuracy of the model in generating observed covariance matrix. GFI value must be between 0 and 1. Although in theory GFI may have a negative value, but it should not happen, because the model has a negative value of GFI is the worst model of all existing models [10]. The model has a GFI values $>0.90$ indicate a good model fit.

TABLE V

GOF STATISTICS FOR E-LEARNING INTERFACE ACCEPTANCE MODEL.

\begin{tabular}{|c|c|c|c|}
\hline $\begin{array}{l}\text { Goodness of } \\
\text { Fit } \\
\end{array}$ & $\begin{array}{c}\text { Statistics Measurement } \\
\text { Target } \\
\end{array}$ & Model I & Model II \\
\hline \multicolumn{4}{|c|}{ Absolute Fit Measures } \\
\hline$X^{2}$ & Smaller grades is better & 197.76 & 55.88 \\
\hline NCP & Smaller grades is better & 146.76 & 16.88 \\
\hline SNCP & Smaller grades is better & 1.82 & 0.51 \\
\hline GFI & GFI $\geq 0.90$ & 0.78 & 0.93 \\
\hline RMSR & $\mathrm{RMSR} \leq 0.05$ & 0.80 & 0.31 \\
\hline RMSEA & RMSEA $<0.08$ & 0.158 & 0.061 \\
\hline ECVI & Smaller grades is better & 2.19 & 1.16 \\
\hline \multicolumn{4}{|c|}{ Incremental Fit Measures } \\
\hline TLI or NNFI & $\mathrm{I}_{\mathrm{NNFI}} \geq 0.90$ & 0.90 & 0.98 \\
\hline NFI & $\mathrm{NFI} \geq 0.90$ & 0.90 & 0.97 \\
\hline AGFI & $\mathrm{AGFI} \geq 0.90$ & 0.66 & 0.85 \\
\hline RFI & $\mathrm{RFI} \geq 0.90$ & 0.87 & 0.95 \\
\hline IFI & $\mathrm{IFI} \geq 0.90$ & 0.92 & 0.99 \\
\hline CFI & $\mathrm{CFI} \geq 0.90$ & 0.92 & 0.99 \\
\hline \multicolumn{4}{|c|}{ Parsimonious Fit Measures } \\
\hline PGFI & Higher grades is better & 0.51 & 0.46 \\
\hline Normed $X^{2}$ & $\begin{array}{l}\text { Minimun grades: } 1.0 \\
\text { Maximum grades: } 3.0\end{array}$ & 4.10 & 1.50 \\
\hline PNFI & Higher grades is better & 0.69 & 0.57 \\
\hline AIC & $\begin{array}{l}\text { Smaller grades (positive) is } \\
\text { better }\end{array}$ & 251.76 & 133.88 \\
\hline CAIC & $\begin{array}{l}\text { Smaller grades (positive) is } \\
\text { better }\end{array}$ & 353.10 & 280.27 \\
\hline
\end{tabular}

Adjusted Goodness of Fit Index (AGFI) is the same as GFI, but had to adjust the influence of degrees of freedom in a model. Fit model is one that has the value of AGFI $=0.90$. RMSEA is an indicator of model fit most informative. RMSEA measures the deviation of the parameter values in a model with population covariance matrix. RMSEA values> 0.05 identifies the model fit and RMSEA values ranging between 0.08 states that the model has a forecast error rasionable. RMSEA values ranged from 0.08 to 0.1 indicates that the model had sufficient fit, but if the value of RMSEA> 0.1 states that the value of a model fit very ugly.

Expected cross validation index (ECVI) was used to assess the trend that the model, in a single sample, can be cross-validated on the sample size and the same population. ECVI measures the deviation between the fitted (model) covariance matrix of the sample being analyzed and the covariance matrix that would be obtained in other samples but has the same sample size. ECVI value models ECVI lower than that obtained in the model saturated and independence models, indicating that the model is fit. AIC and CAIC are used to assess the issue of parsimony in the assessment of model fit. AIC and CAIC are used in the comparison of two or more models, where the value of AIC and CAIC smaller than the AIC model of saturated and independence means having a better model fit.

Normed Fit Index (NFI) and the Comparative Fit Index (CFI) ranges between 0 and 1 are derived from the comparison between the model and the hypothesized model of independence. A model is said to fit if it has a value of NFI and CFI> 0.90. While the Nonnormed Fit Index (NNFI), is used to overcome the problems arising from the complexity of the model. Similarly, Incremental Fit Index (IFI) is used to overcome the problem of parsimony and sample size associated with NFI. While Relative Fit Index (RFI) is used to measure the fit where values between 0 and 1 .

\section{Conclusions and Recommendations}

\subsection{Conclusion}

This paper presents how to develop the construct model among user's style, usability and user benefit as indicator variables to measure the latent variable of user e-learning interface acceptance. According to research questioners analysis and Goodness of Fit measurement, it is shown that the high reliability in this study indicates that an indicator variable has a consistently high in measuring latent constructs. Test reliability by using two types of measurements that measure construct composite reliability and variance extracted measure. According to t-value, loading factors, and the relative suitability value of each structural equation model, we can conclude that the interface User Acceptance Model for E-learning in this study can be accepted.

\subsection{Recommendations}

This study has become one alternative model to get the user acceptance of e-learning interface. Hopefully this model can be considered in developing an e-learning application in the future. 


\section{References}

[1] Virginio C., Massimo C., Marco P., Perspectives and Challenges in E-learning: towards Natural Interaction Paradigms, Journal of Visual Languages and Computing 15 (2004) 333-345

[2] Graham, C. Blended learning systems. Definitions, current trends and future directions. In C. Bonk \& C. Graham, The handbook of blended learning: Global perspectives, local designs. 2006 San Francisco: John Wiley and Sons.

[3] Guralnick, D. "How to Design Effective, Motivating User Interfaces." American Society for Training \& Development TechKnowledge Conference, 2006. Denver, $\mathrm{CO}$.

[4] A. Seffah, Moh. Donyaee, R.B. Kline, Harkirat K. Padda. Usability measurement and metrics, A consolidated model, Software Qual J, 14: 159-178. 2006

[5] B. Olga. A. The metrics for quantitative evaluation of user interface usability construction methodology. SPECOM: 9th Conference Speech and Computer St. Petersburg, September 20-22, 2004. Russia

[6] Dedic-Marcovic, Influence of learning styles on graphical user interface for e-learning. Modern Business School Belgrade, Serbia 2012.

[7] Sfenrianto, Hasibuan ZA, Suhartanto H., The Influence Factors of Inherent Structure in ELearning Process. International Journal of Education, E-business, e-Management and elearning. 2011

[8] Dagez \& Baba, Applying Neural Network Technology in Qualitative Research for Extracting Learning Style to Improve Elearning Environment, IEEE. 2008.

[9] Yang, Ping and Kong et.al. Study on personality learning in E-learning. International Conference on E-Learning, E-Business, Enterprise Information Systems, and E-Government, 2009.

[10] Ma,Wang and Liang. The e-Learning System Model Based on Affective Computing, Seventh International Conference on Webbased Learning, 2008.

[11] Nielsen, J. Usability Engineering. CA: Academic Press, 1993. San Diego

[12] Park and Lim, A structured methodology for comparative evaluation of user interface designs using usability criteria and measures, International Journal of Industrial Ergonomics 23:379-389, 1999.

[13] D.Marghescu, Usability Evaluation of Information Systems: A Review of Five International Standards Information Systems Development: Challenges in Practice, Theory, and Education, Vol.1, 2009.

[14] A.Fernandez, E. Insfran, S. Abrahão. Towards a Usability Evaluation Process for Model-Driven Web Development, I-USED '09, August 24, 2009, Upssala, Sweeden

[15] Fernandez, Insfran, and Abrahão. Integrating a Usability Model into Model-Driven Web Development Processes. Web Information Systems Engineering - WISE 2009.

[16] Ríos A, García A and Bonillo. Usability: A Critical Analysis and a Taxonomy. Intl journal of Human -Computer Interaction 26(1), 53-74, 2010

[17] K Marçal de Oliveira. New research challenges for user interface quality evaluation Interaction Homme-Machine ACM New York, 2010. USA Computer Society pp. 287-294 ISBN: 978-1-45030410-8 IEEE

[18] Shin H. Dong, Kim T \& Jung S. Towards a Conceptualizing Social Presence in 3DTV. iConference 2011, February 8-11, 2011, Seattle, WA, USA

[19] Joreskog, Karl.G.dan D.Sorbom. LISREL 8: User's Reference Guide. 1996. Chicago: SSI, Inc 